\title{
HYGIENIZATION OF SURPLUS ACTIVATED SLUDGE BY DRY ICE
}

\author{
HIGIENIZACJA OSADU NADMIERNEGO SUCHYM LODEM
}

\begin{abstract}
The presence of pathogenic microorganisms in sewage sludge is one of the crucial factors affecting their use in agriculture and in nature. An appropriate method of sludge hygienization can contribute to the reduction of the presence of pathogenic microbes in the sludge or to their complete elimination. This study presents the possibility of using dry ice in the hygienization of surplus activated sludge. The scope of survey covered microbiological as well as physiochemical analyses of the sludge. The microbiological analyses conducted show the hygienization effect of dry ice on surplus activated sludge such as the reduction of the total number of bacteria as well as of pathogenic bacteria. In the case of sludge to dry ice 1:1 voluminal ratio, the total number of bacteria has been reduced by $76 \%$, the number of Salmonella sp. rods by $90 \%$, and Clostridium perfringens by $85 \%$. The results of physiochemical analyses confirmed the destructive effect that dry ice has over microorganisms. The disintegration of microbes by means of dry ice contributed to the increase of supernatant liquid turbidity and to the release of organic matter. For the sludge to dry ice 1:1 voluminal ratio, an increase in turbidity of supernatant liquid by $320 \mathrm{mg} \mathrm{SiO}_{2} \mathrm{dm}^{-3}$ has been proven, as well as an increase in the value of $\mathrm{COD}_{\mathrm{Cr}}$ by $549 \mathrm{mg} \mathrm{O}_{2} \mathrm{dm}^{-3}$, which indicates the release of organic matter into the liquid phase.
\end{abstract}

Keywords: surplus activated sludge, dry ice, Salmonella sp., Clostridium perfringens

\section{Introduction}

A primary objective of sludges treatment is their stabilizing. Stabilized sludges have a favourable chemical composition, excellent soil-forming properties and generally return water well. However, the conditioning processed being used do not provide a product that is completely safe in terms of sanitary matters due to the fact that they are occupied by bacteria, viruses, parasitic worms, fungi, protozoa and other microorganisms. They include both pathogenic microorganisms, dangerous to human, and saprophytic ones, neutral from the sanitary point of view. The presence of pathogenic organisms in sewage sludges is therefore a sanitary hazard for the environment.

The assessment of a sanitary condition of sludges is based on the indirect conclusion on the content of pathogenic bacteria and eggs of intestinal parasites and is based on

\footnotetext{
${ }^{1}$ Department of Microbiology and Environmental Biotechnology, Institute of Environmental Protection and Engineering, University of Bielsko-Biala, ul. Willowa 2, 43-309 Bielsko-Biała, Poland, phone +48338279157

*Corresponding author: enowicka@ath.bielsko.pl
} 
determining so called sanitary indicator. Until recently, the species being a sanitary indicator among bacteria was a lactose-positive rods Escherichia coli. Currently, under the Regulation of the Minister of the Environment [1], a new bacteria indicator Salmonella sp. is being used in sanitary assessment. Salmonella sp. is a relatively anaerobic rods, commonly present in sewage, sewage sludges and contaminated water. The time of its survival in the environment is approximately 3 months [2]. The role of Salmonella sp. rods in the pathogenesis of human infections has increased significantly in recent years [3]. A minimum infectious dose for this pathogen is from 10 to $10^{10}$ of cells [2]. Salmonella sp. is, among others, the cause of $86 \%$ of gastroenteritis met [3], typhoids, multi-organ infections and sepsis [4,5]. The effect of its toxic actions results from the release of lipopolysaccharide endotoxin [6].

Clostridium perfringens are spore-forming rods, present in sewage, sewage sludges, soil contaminated with faeces and the gastrointestinal tract of humans and animals. It is a strictly anaerobic bacteria, able to survive in the environment for a long period of time due to the ability of creating conditions of unfavourable endospores. It may cause wound infections or nosocomial infections and food poisoning as a result of consuming food or water contaminated with spores that are resistant to temperature and disinfection $[2,4,7]$.

The risk of infecting the environment with pathogens originating from sewage sludges requires seeking new methods to improve their sanitary status. Some of the methods used in sewage biotechnology are used for sewage sludges disintegration: thermal energy [8, 9], enzymes [10, 11], ozonation [12, 13], acidification [14], alkalization [15], the use of high pressure [16-18], mechanical grinding [19], ultrasounds [20-24], hydrodynamic cavitation [25-27], microwave radiation [27-31].

As a result of disintegration the disruption of cell envelopes takes place (cytoplasmic membrane and/or cell wall), which causes the destruction of microorganisms and thus the release of the organic substrate and intracellular enzymes into the environment [31]. On this basis, the concept of the use of dry ice to hygienization of surplus activated sludge was revealed.

Dry ice is a carbon dioxide in the solid state which is formed by expansion of liquid carbon dioxide under normal conditions (temperature of $273 \mathrm{~K}\left(-0.15^{\circ} \mathrm{C}\right)$, pressure of $1013.25 \mathrm{hPa}$ ). The dry ice sublimes at $-78.5^{\circ} \mathrm{C}$ and a pressure of $1013.25 \mathrm{hPa}$. Its heat of sublimation is $573 \mathrm{~kJ}$, which means that it is approximately 3.3 times more effective coolant than water ice (with the same volume). Its specific gravity comprises in the range from 1.2 to $1.6 \mathrm{~kg} / \mathrm{dm}^{3}$, and its hardness on the Mohs scale is 2, which corresponds to the hardness of gypsum. It is anhydrous, non-flammable, non-toxic and has no smell or taste [32].

It is widely used as a coolant in laboratories, industrial cold rooms, alone or as a constituent of cooling mixtures, and prevents the growth of fungi and bacteria; therefore it is used for transportation of perishable food products. In temperature baths, dry ice is usually used in the form of cooling mixture, consisting of crushed dry ice and organic solvent of a low freezing point $\left(>-80^{\circ} \mathrm{C}\right)$, for example, acetone or ethanol [33]. Today it is also used for industrial cleaning.

The aim of the study was to demonstrate the destructive effect of dry ice on the structure of surplus activated sludge, shown by the release of organic matter, changes in turbidity of supernatant liquor and hygienization. 


\section{Material and methods}

The experimental material was surplus activated sludge from sewage treatment plants, using advanced biological wastewater treatment processes, involving the simultaneous removal of organic compounds and nitrogen and phosphorus. The sewage treatment plant was designed for the flow of $120000 \mathrm{~m}^{3} \mathrm{~d}^{-1}$. At the moment, the amount of draining off sewage is approximately $90000 \mathrm{~m}^{3} \mathrm{~d}^{-1}$, the wastewater retention time is about 14 days and the concentration of the active sludge in the bioreactor is about $4500 \mathrm{mg} \mathrm{dm}^{-3}$.

\section{Hygienization/disintegration of sludge by dry ice}

Hygienization/disintegration by freezing/thawing a sample of $1 \mathrm{dm}^{3}$ of surplus activated sludge was executed with dry ice. For hygienization/disintegration of surplus activated sludge the following volume ratios of the surplus sludge to dry ice were used, ie $1: 0.25 ; 1: 0.5 ; 1: 0.75 ; 1: 1$.

The time in which samples stay in the frozen state depends on the applied volume of the dry ice:

- for the volume ratio of sludge to dry ice $1: 0.25,1.5$ hours,

- for the volume ratio of sludge to dry ice $1: 0.5,2$ hours,

- for the volume ratio of sludge to dry ice $1: 0.75,3$ hours,

- for the volume ratio of sludge to dry ice $1: 1,4.5$ hours.

\section{Microbiological analysis}

The samples of surplus sludge for microbiological analysis were collected into sterilized hermetically sealed glass containers with a volume of $250 \mathrm{~cm}^{3}$. The material was delivered to the laboratory within 15 to 30 minutes from its collection.

The analyses in surplus sludge were performed before and after the hygienization process by dry ice in terms presence bacteria of Salmonella and Clostridium perfringens. The determinations of microorganisms were made in accordance with Project Routes (2011-2014), Novel processing routes for effective sewage sludge management procedure. Innovative system solutions for municipal sludge treatment and management. Grant agreement $n^{\circ} 265156$ [34]. The studies related also to the total number of bacteria contained in the surplus sludge before and after the destruction of the dry ice.

As the culture media, the following were used: Nutrient Agar, Buffered Peptone Water supplemented Novobiocin, Rappaport-Vassiliadis Medium, Hektoen Enteric, SMS Agar, SPS Agar. In order to verify the taxonomic classification of Salmonella sp. the API 20E biochemical test and the MUCAP test were used.

\section{Salmonella sp. - principle of the method}

This is a method recovery of sub-lethaly Salmonella sp. In this method detection of Salmonella sp. is undertaken in main five steps:

- pre-enrichment of bacteria in primary selective medium (Buffered Peptone Water Medium),

- enrichment in secondary selective medium which inhibits the growth of microorganisms but promotes that of salmonellae (selective enrichment), (Buffered Peptone Water Medium supplemented Novobiocin), 
- $\quad$ inoculation in selective medium to presumptively confirm the presence of Salmonella sp. (Rappaport-Vassiliadis Medium, SMS Agar),

- culture on a second selective medium to definitely confirm the presence of Salmonella sp. (Hektoen Enteric Agar),

- confirmation of the presumptive Salmonella sp. with a biochemical assay (API 20E, MUCAP test).

\section{Clostridium perfringens - principle of the method}

A thermal shock at $80^{\circ} \mathrm{C}$ for 10 minutes is performed to the samples in order to removal all the accompanying microbiota and the vegetative forms of $C$. perfringens. Then, the sample is added into an empty tube and SPS agar is poured. Tubes are incubated anaerobically at $(44 \pm 1)^{\circ} \mathrm{C}$ for $(24 \pm 1) \mathrm{h}$. The presence of spores $C$. perfringens is indicated by black colonies resulting from the precipitation of the sulphide produced by $C$. perfringens with the ferric citrate of the medium.

\section{Total number of bacteria}

The number of bacteria (cfu) in $1 \mathrm{~g}$ of the surplus sludge before and after hygienization by dry ice, presented graphically, was the arithmetic average of the three test series.

\section{Physicochemical analysis}

In the surplus sludge samples, before and after the process of disintegration by dry ice, the turbidity of supernatant liquor and $\mathrm{COD}_{\mathrm{Cr}}$ value, expressing the release of organic matter, were determined. The physicochemical analyses were performed based on the methodology contained in the Standard Methods for Examination of Water and Wastewater, $19^{\text {th }}$ Edition [35].

The presented here investigations were performed in 10 stages, arithmetic average and standard deviation was counts. Standard deviation was determination according to estimator of highest credibility in STATISTICA 6.0.

\section{Results and discussion}

Large amounts of sludge are produced in biological wastewater treatment plants. Since the sludge is highly contaminated, it has to undergo proper stabilization before it is disposed or utilized in an environmentally safe way. The paper presents a potential application of disintegration by freezing/thawing for sewage sludge (mainly surplus activated sludge) and sanitary condition enhancement.

The dry ice used caused the destruction of microorganisms, and thus contributed to a partial hygienization of surplus sludge, which is confirmed by the results of the microbiological analyzes (Figs. 1-3). In the surplus activated sludge not subjected to hygienization by dry ice, the total number of bacteria was $16790610 \mathrm{cfu} \mathrm{g}_{\text {d.w. }}{ }^{-1}$ (Fig. 1) and for the sludge subject to hygienization the number was reduced:

- for the volume ratio of sludge to dry ice $1: 0.25$, by $8576238 \mathrm{cfu} \mathrm{g}_{\text {d.w. }}{ }^{-1}$ (Fig. 1),

- for the volume ratio of sludge to dry ice $1: 0.5$, by $10489285 \mathrm{cfu} \mathrm{g}_{\text {d.w. }}{ }^{-1}$ (Fig. 1),

- for the volume ratio of sludge to dry ice $1: 0.75$, by $11739829 \mathrm{cfu}^{\mathrm{d}} \mathrm{g}_{\text {d.w. }}{ }^{-1}$ (Fig. 1),

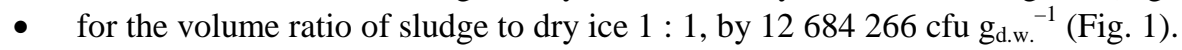




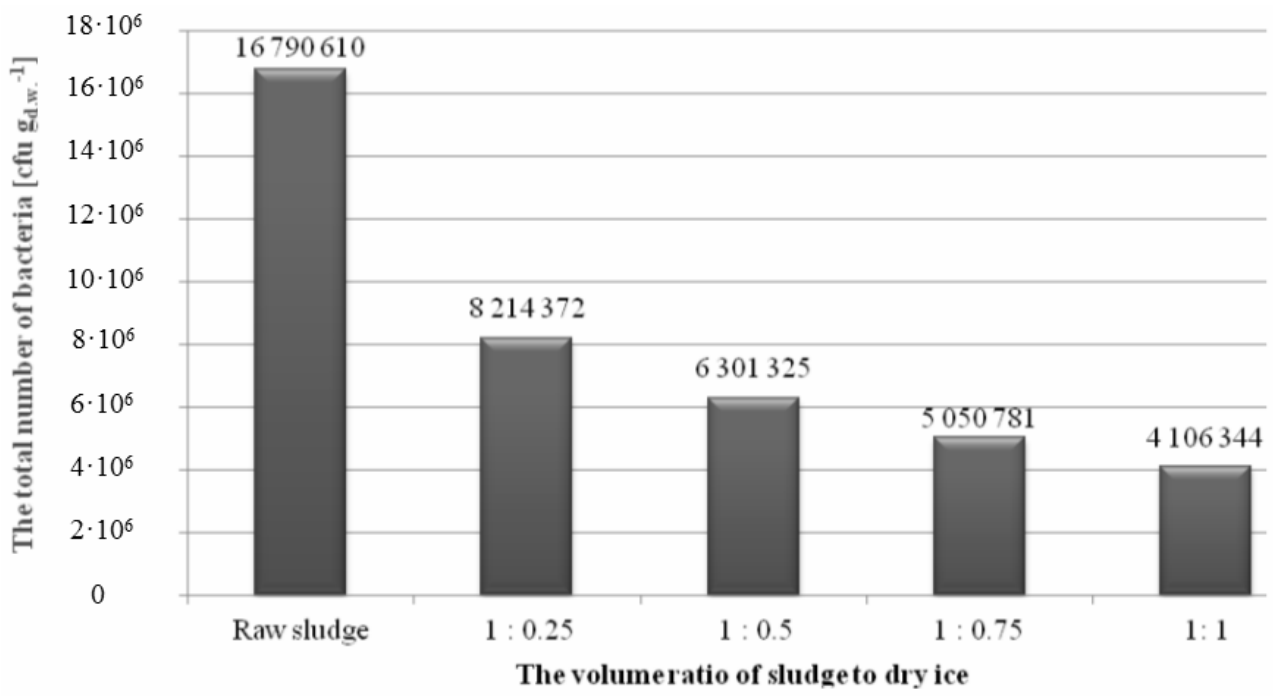

Fig. 1. The total number of bacteria (cfu) per $1 \mathrm{~g}$ of the surplus sludge depending on the volume ratio of sludge to dry ice

Sewage sludge commonly contains high amounts of human pathogenic bacteria excreted in feces and urine. The enteric pathogenic bacterial constituents include Salmonella spp., Listeria spp., Escherichia coli (enterotoxigenic and enteropathogenic variants), Campylobacter spp., Clostridium spp. and Yersinia spp.

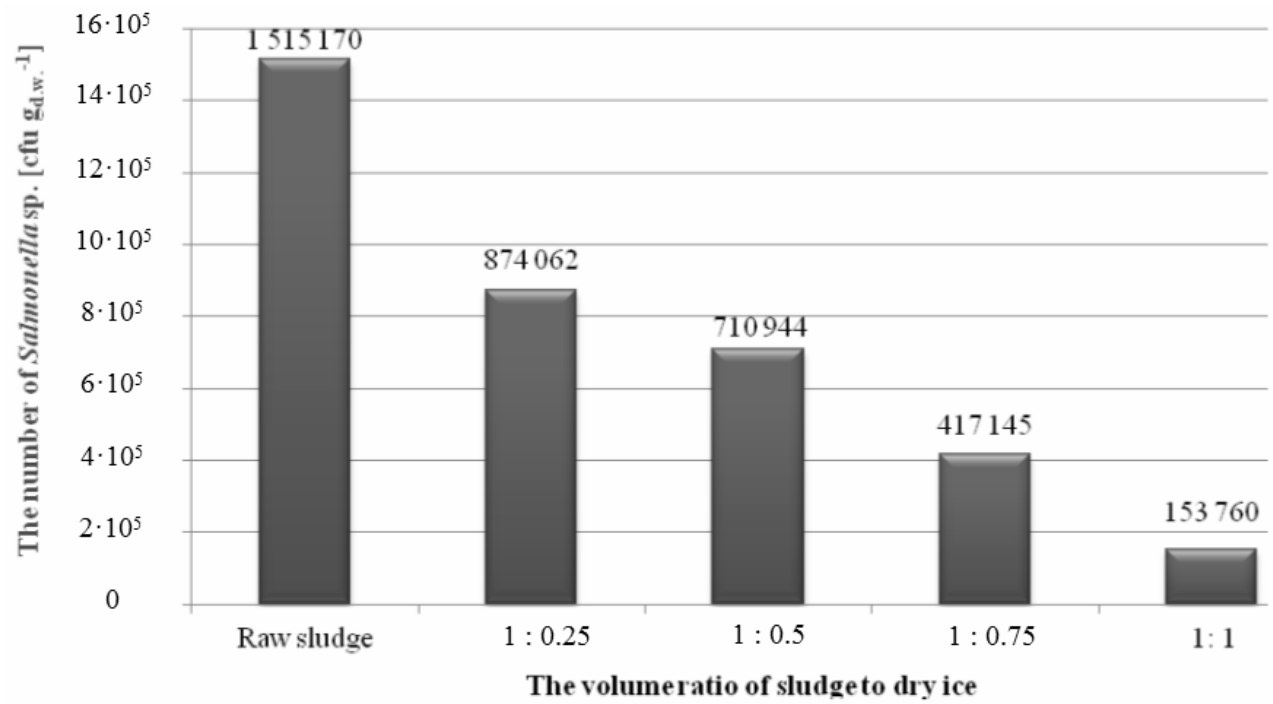

Fig. 2. The number of Salmonella sp. rods (cfu) per $1 \mathrm{~g}$ of the surplus sludge depending on the volume ratio of sludge to dry ice 
Additionally, these organisms have a strong ability to persistently adapt to changes in the surrounding environment for survival and can be relatively resistant to commonly employed sludge stabilization techniques [36, 37]. The health risks related to these pathogens depends on the prior sludge treatments applied (pre-treatment processes), as well as their ability to maintain virulence properties during both storage and distribution on a field used for grazing or food harvesting purposes [38-41].

The sludge hygienization is one of the objectives and benefits of the treatment by freezing/thawing. The dry ice had a destructive effect on bacteria indicator of sanitary assessment of sewage sludge. The number of rods Salmonella in $1 \mathrm{~g}$ of the surplus sludge not subject to hygienization by dry ice amounted to $1515170 \mathrm{cfu} \mathrm{g}_{\text {d.w. }}{ }^{-1}$ (Fig. 2), while after the process hygienization, this number decreased:

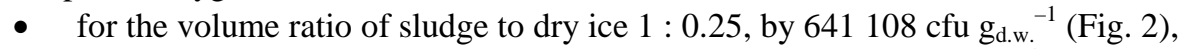

- for the volume ratio of sludge to dry ice $1: 0.5$, by $804226 \mathrm{cfu} \mathrm{g}_{\text {d.w. }}{ }^{-1}$ (Fig. 2),

- for the volume ratio of sludge to dry ice $1: 0.75$, by $1098025 \mathrm{cfu} \mathrm{g}_{\text {d.w. }}{ }^{-1}$ (Fig. 2),

- for the volume ratio of sludge to dry ice 1: 1, by $1361410 \mathrm{cfu} \mathrm{g}_{\text {d.w. }}{ }^{-1}$ (Fig. 2).

A potential indicator of the sanitary quality of sewage sludge, which is mentioned in the literature [42] is Clostridium perfringens.

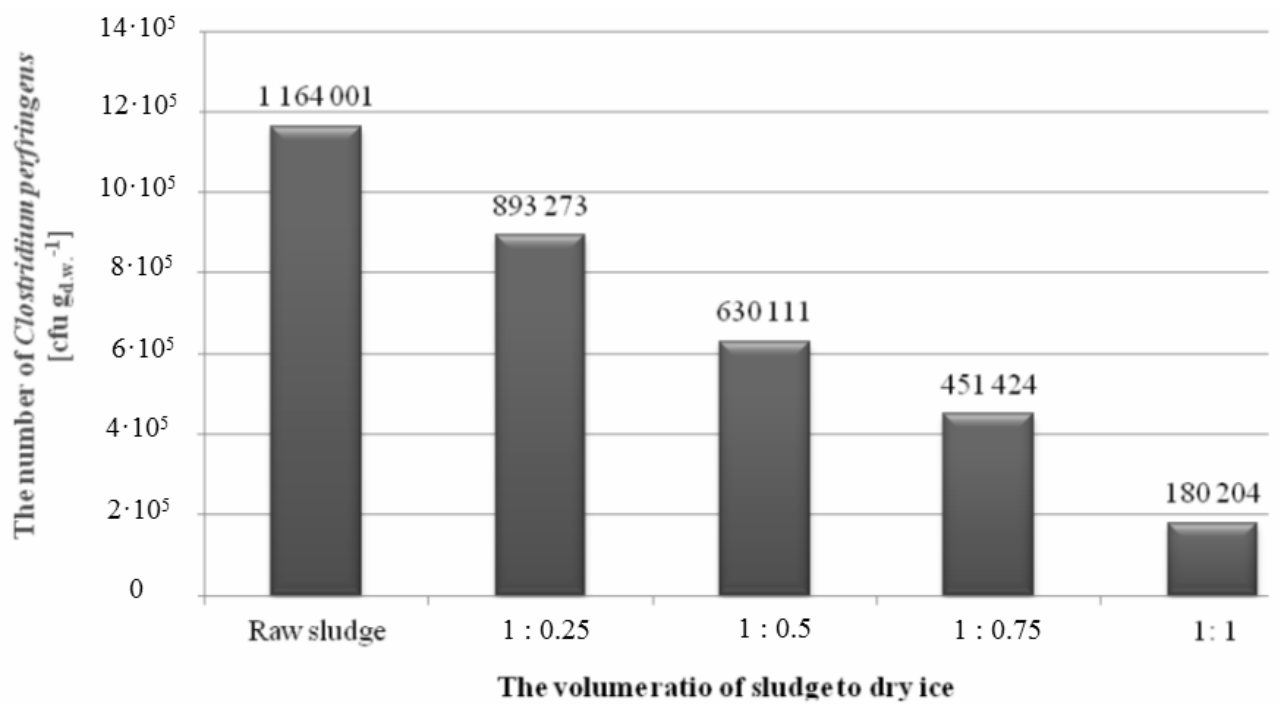

Fig. 3. The number of Clostridium perfringens rods (cfu) per $1 \mathrm{~g}$ of the surplus sludge depending on the volume ratio of sludge to dry ice

There was a gradual elimination of the Clostridium perfringens bacteria caused by the growth of the volume ratio of the sludge to dry ice. The number of Clostridium perfringens rods in the sludge not subject to hygienization by dry ice amounted to $1164001 \mathrm{cfu} \mathrm{g}_{\text {d.w. }}{ }^{-1}$ (Fig. 3), while after the hygienization process, the number was reduced:

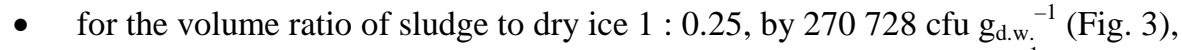

- for the volume ratio of sludge to dry ice $1: 0.5$, by $533890 \mathrm{cfu} \mathrm{g}_{\text {d.w. }}{ }^{-1}$ (Fig. 3), 
- for the volume ratio of sludge to dry ice $1: 0.75$, by $712577 \mathrm{cfu} \mathrm{g}_{\mathrm{d} . w .}{ }^{-1}$ (Fig. 3),

- for the volume ratio of sludge to dry ice 1 : 1, by $983797 \mathrm{cfu} \mathrm{g}_{\mathrm{d} . w .}{ }^{-1}$ (Fig. 3).

The efficiency of sludge hygienisation depended on for the volume ratio of sludge to dry ice.

Mechanical damages of cells and osmotic shock were the cause of death of microorganisms during freezing. The mechanical damages were caused by the formation of ice crystals in the surrounding environment of cell and inside the cell. Extracellular crystals increasing in the freezing process were destroying cells of microorganisms present among them [43]. The formation of intracellular crystals damage caused biomembrans damage and change of their properties leading to leakage of intracellular substances into the environment.

Several disintegration processes are developed: mechanical, thermal, chemical, biological. Although the methods are different in character, the aim of all of them is partial or complete bacteria cells disintegration, ie destruction and release of organic substances present inside cells to the liquid phase of the sludge.

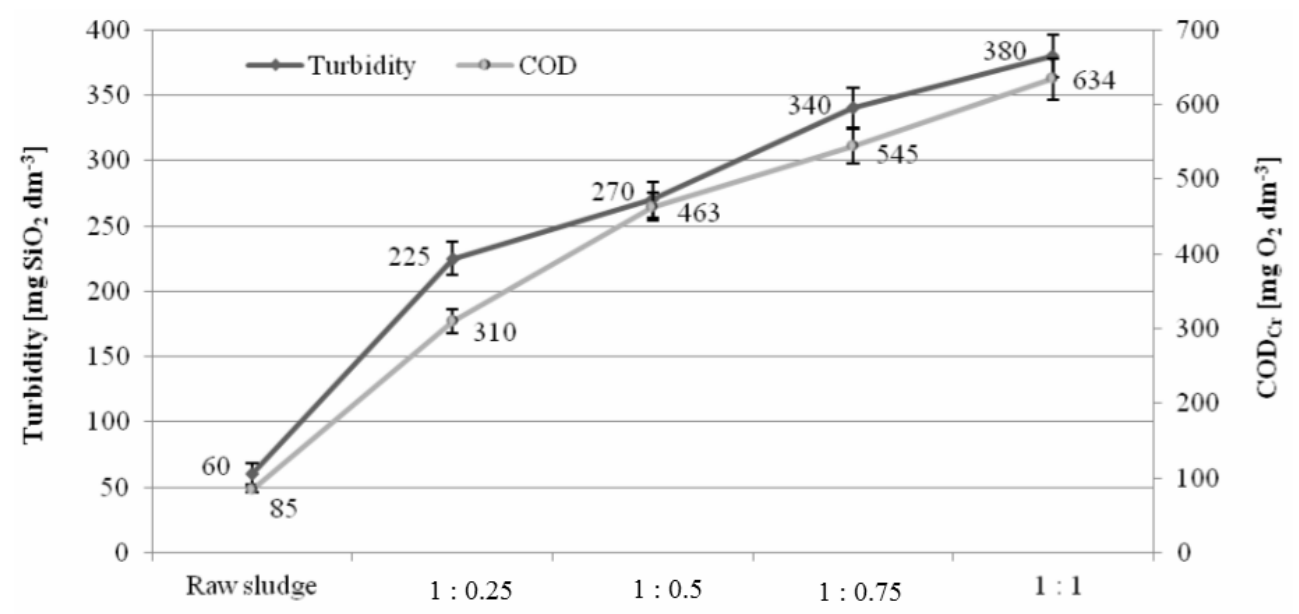

The volume ratio of sludge to dry ice

Fig. 4. The released organic matter (expressed as $\mathrm{COD}_{\mathrm{Cr}}$ ) and the turbidity of supernatant liquor before and after the process of disintegration by dry ice

The results of physicochemical analyzes confirmed the destructive action of dry ice on microorganisms. Release of organic matter expressed as an increase in soluble $\mathrm{COD}_{\mathrm{Cr}}$ value was considered as a tool for measurement of decay bacteria effects (Fig. 4). According to the methodology used, the process of disintegration by dry ice was carried out for the volume ratio of sludge to dry ice $1: 0.25 ; 1: 0.5 ; 1: 0.75 ; 1: 1$. The disintegration of the surplus sludge by dry ice resulted in the release of organic matter expressed with COD $_{\mathrm{Cr}}$ value (Fig. 4). The greater the dose of the dry ice used for the destruction of the sludge, the higher the value of $\mathrm{COD}_{\mathrm{Cr}}$ in the supernatant liquor (Fig. 4). The value of $\mathrm{COD}_{\mathrm{Cr}}$ in the supernatant liquor of the surplus sludge not subject to disintegration by dry ice was $85 \mathrm{mg} \mathrm{O}_{2} \mathrm{dm}^{-3}$ (Fig. 4), while after the disintegration for the volume ratio of the surplus 
sludge to dry ice $1: 1$, the value of $\mathrm{COD}_{\mathrm{Cr}}$ increased to $634 \mathrm{mg} \mathrm{O}_{2} \mathrm{dm}^{-3}$ (Fig. 4). It was over sevenfold increase of $\mathrm{COD}_{\mathrm{Cr}}$. Similar results using freezing method had Montusiewicz et al [44]. Destruction of the microbial cells by dry ice, as well as other methods of the disintegration, has a pronounced impact on released of organic matter to aqueous phase [9, 23, 45-46].

The microbiological destruction of the structure of flock by dry ice contributed to the increase in turbidity of the liquid phase of the sludge, mainly due to the release of intracellular and extracellular substance of polymers (Fig. 4). In the surplus sludge not subject to disintegration by dry ice, the turbidity of supernatant liquor was $60 \mathrm{mg} \mathrm{SiO} \mathrm{dm}^{-3}$ (Fig. 4), and after the process of destruction, for the volume ratio to dry ice 1: 1, was increased by $320 \mathrm{mg} \mathrm{SiO}_{2} \mathrm{dm}^{-3}$ (Fig. 4).

The obtained microbiological results, allow to conclude that hygienization by dry ice may become a new and favourable method of improving sewage sludges hygienization processes.

\section{Conclusions}

1. The destruction of the surplus sludge by dry ice carried out, helped to reduce the total number of bacteria and pathogenic bacteria, and thus the partial hygienization of the surplus sludge. The total number of bacteria in $1 \mathrm{~g}$ of the volume ratio of the sludge to dry ice 1: 1 was reduced by $76 \%$, the number of Salmonella sp. rods decreased by $90 \%$, while the number of Clostridium perfringens rods decreased by $85 \%$.

2. The disintegration of the surplus activated sludge by dry ice resulted in the release of organic matter into the liquid phase and the increase in turbidity of supernatant liquor. $\mathrm{COD}_{\mathrm{Cr}}$ value increased by $549 \mathrm{mg} \mathrm{O}_{2} \mathrm{dm}^{-3}$, and the turbidity of liquid by $320 \mathrm{mg} \mathrm{SiO}_{2} \mathrm{dm}^{-3}$.

\section{References}

[1] Rozporządzenia Ministra Środowiska (DzU 2010, Nr 137, poz. 924).

[2] Bitton G. Wastewater Microbiology, Third Edition. New Jersey: John Wiley and Sons; 2005. DOI: 10.1002/0471717967.

[3] Bień J. Osady ściekowe. Teoria i praktyka. Częstochowa: Wyd. Politechniki Częstochowskiej; 2007.

[4] Virella G. Microbiology and Infectious Diseases. Baltimore: Williams \& Wilkins a Waverly Company; 2000 .

[5] Lunn AD, Fàbrega A, Sánchez-Céspedes J, Vila J. Research Support, Non-U.S. Gov't. 2010;13:15-20. DOI: 10.2436/20.1501.01.107.

[6] Schlegel GH. Mikrobiologia ogólna. Warszawa: Wyd Nauk PWN; 2005.

[7] Sirous M, Namaki S, Mirshafiey A. PhD. Clostridia. J Chinese Clinic Medic. 2009;4:35-47.

[8] Wilson ChA, Novak JT. Water Res. 2009;43:4489-4498. DOI: 10.1016/j.watres.2009.07.022.

[9] Appels L, Degrève J, Van der Bruggen B, Van Impe J, Dewil R. Biores Technol. 2010;101:5743-5748. DOI: 10.1016/j.biortech.2010.02.068.

[10] Barjenbruch M, Kopplow O. Adv Environ Res. 2003;7:715-720. DOI: 10.1016/S1093-0191(02)00032-1.

[11] Roman HJ, Burgess JE, Pletschke BI. Afric J Biotechnol. 2006;5:963-967. DOI: 10.5897/AJB06.154.

[12] Weemaes M, Grootaerd H, Simoens F, Verstraete W. Water Res. 2000;34:2330-2336. DOI: 10.1016/S0043-1354(99)00373-5.

[13] Campos JL, Otero L, Franco A, Mosquera-Corral A, Roca E. Biores Technol. 2009;100:1069-1073. DOI: 10.1016/j.biortech.2008.07.056.

[14] Woodard SE, Wukasch RF. A hydrolysis/thickening/filtration process for the treatment of waste activated sludge. Water Sci Technol. 1994;30:29-38.

[15] Vlyssides AG, Karlis PK. Biores Technol. 2004;91:201-206. DOI: 10.1016/S0960-8524(03)00176-7. 
[16] Gogate PR, Pandit AB. Hydrodynamic cavitation reactors: a state of the art review. Rev Chem Eng. 2001;17:7-85.

[17] Grübel K, Machnicka A, Suschka J. Scum hydrodynamic disintegration for waste water treatment efficiency upgrading. Ecol Chem Eng S. 2009;16:359-367.

[18] Machnicka A, Grübel K, Suschka J. The use hydrodynamic disintegration to accelerate anaerobic digestion of surplus activated sludge. Water Environ Res. 2009;81:1-7.

[19] Müller J. Disintegration as key-stop in sewage sludge treatment. Water Sci Technol. 2000;41:123-139.

[20] Bień J, Szparkowska J. Alkaliczne i ultradźwiękowe kondycjonowanie osadu nadmiernego przed procesem stabilizacji beztlenowej. GWiTS. 2004;9:316-320.

[21] Wang F, Lu S, Ji M. Ultrasonics. Sonochemistry. 2006;13:334-338. DOI: 10.1016/j.ultsonch.2005.04.008.

[22] Antoniadis A, Poulios I, Nikolakaki E, Mantzavinos D. J Hazard Mater. 2007;146:492-495. DOI: 10.1016/j.jhazmat.2007.04.065.

[23] Zhang G, Zhang P, Yang J, Chena Y. J Hazard Mater. 2007;145:515-519. DOI: 10.1016/j.jhazmat.2007.01.133.

[24] Rusin A, Machnicka A. Kawitacja ultradźwiękowa w higienizacji osadu czynnego nadmiernego. GIG. 2011;3:73-80.

[25] Machnicka A, Grübel K, Suschka J. The use hydrodynamic disintegration as means to improve anaerobic digestion of activated sludge. Water SA. 2009;35:129-132.

[26] Machnicka A, Grübel K, Rusin A. Ecol Chem Eng S. 2012;19:415-421. DOI: 10.2478/v10216-011-0031-x.

[27] Radosz M. Badania nad możliwością zastosowania mikrofal do higienizacji osadów ściekowych. GWiTS. $2005 ; 2: 24-26$.

[28] Janosz-Rajczyk M, Tomska A. Wpływ pola magnetycznego na proces oczyszczania ścieków metodą osadu czynnego. GWiTS. 2006;2:28-31.

[29] Kennedy KJ, Thibault G, Droste RL. Microwave enhanced digestion of aerobic SBR sludge. Water SA. 2007;33:261-270.

[30] Dębowski M, Zieliński M. Możliwość zastosowania promieniowania mikrofalowego w procesach suszenia osadów powstających podczas oczyszczania ścieków. Woda Ścieki. 2009;1:8-11.

[31] Grübel K, Machnicka A. Oddziaływanie promieniowania mikrofalowego na osad czynny. Nauka Przyr Technol. 2011;5:67.

[32] Cotton A, Wilkinson G, Gaus PL. Chemia nieorganiczna. Warszawa: Wyd Nauk PWN; 1995.

[33] Jean DS, Lee DJ, Chang CY. Adv Envir Res. 2001;5:145-150. DOI: 10.1016/S1093-0191(00)00052-6.

[34] Project Routes (2011-2014), Novel processing routes for effective sewage sludge management. Innovative system solutions for municipal sludge treatment and management. Grant agreement $\mathrm{n}^{\circ} 265156$. Methodology of detection and enumeration of spores of Clostridium perfringens and Salmonella MPN in sludge, soils and organic fertilizers: Pour plate method for quantification, University of Barcelona.

[35] Clesceri LS, Eaton AD, Greenberg AE, Franson MA. Standard methods for the examination of water and wastewater : 19th edition supplement. Washington: American Public Health Association; 1996.

[36] Sahlström L. Biores Technol. 2003;87:161-166. DOI: 10.1016/S0960-8524(02)00168-2.

[37] Walczak M, Lalke-Porczyk E. Occurrence of bacteria salmonella sp. in sewage sludge used in agriculture. Environ Protect Eng. 2009;35:5-12.

[38] Hargreaves JC, Adl MS, Warman PR. Ecosyst Environ. 2008;123:1-14. DOI: 10.1016/j.agee.2007.07.004.

[39] Watanabe H, Kitamura T, Ochi S, Ozaki M. Water Sci Technol. 1997;36:25-32. DOI: 10.1016/S0273-1223(97)00503-9.

[40] Dumonten S, Dinel H, Baloda SB. Biological Agricult Horticult. 1999;16:409-430. DOI: 10.1080/01448765.1999.9755243.

[41] Czechowski F, Marcinkowski T. Water Res. 2006;40:1895-1905. DOI: 10.1016/j.watres.2006.02.023.

[42] Dudley DJ, Guentzel MN, Ibarra MJ, More BE, Sagik BP. Applied Environmental Microbiology. 1980;39:118-126. DOI: 0099-2240/80/01-0118/09\$02.00/0.

[43] Libudzisz Z, Kowal K, Żakowska Z. Mikroorganizmy i środowiska ich występowania. Warszawa: Wyd Nauk PWN; 2007.

[44] Montusiewicz A, Lebiocka M, Rożej A, Zacharska E, Pawłowski L. Biores Technol. 2010;101:3466-3473. DOI: 10.1016/j.biortech.2009.12.125.

[45] Grübel K, Machnicka A. J Environ Sci Health A - Toxic/Hazard Subst Environ Eng. 2014;49:101-107. DOI: $10.1080 / 10934529.2013 .824738$.

[46] Woon-Ji Pa, Johng-Hwa A. Environ Eng Res. 2011;16:103-109. DOI: 10.4491/eer.2011.16.2.103. 


\title{
HIGIENIZACJA OSADU NADMIERNEGO SUCHYM LODEM
}

\author{
Zakład Mikrobiologii i Biotechnologii Środowiskowej \\ Instytut Ochrony i Inżynierii Środowiska \\ Akademia Techniczno-Humanistyczna w Bielsku-Białej
}

\begin{abstract}
Abstrakt: Obecność mikroorganizmów chorobotwórczych w osadach ściekowych jest jednym z decydujących czynników wpływających na rolnicze i przyrodnicze ich wykorzystanie. Odpowiedni sposób higienizacji osadów może przyczynić się do ograniczenia występowania w nich bakterii patogennych lub całkowitej ich eliminacji. Praca przedstawia możliwość zastosowania suchego lodu do higienizacji osadu nadmiernego. Zakres badań obejmował analizy mikrobiologiczne i fizykochemiczne osadu. Przeprowadzone analizy mikrobiologiczne wykazały higienizujące działanie suchego lodu na osad nadmierny poprzez redukcję ogólnej liczby bakterii i bakterii patogennych. Dla stosunku objętościowego osadu do suchego lodu 1 : 1 ogólna liczba bakterii uległa zmniejszeniu o 76\%, redukcja liczby pałeczek Salmonella sp. o 90\%, natomiast liczba laseczek Clostridium perfringens obniżyła się o $85 \%$. Potwierdzeniem niszczącego działania suchego lodu na mikroorganizmy były wyniki analiz fizykochemicznych. Dezintegracja drobnoustrojów suchym lodem przyczyniła się do wzrostu mętności cieczy nadosadowej i uwolnienia materii organicznej. Dla stosunku objętościowego osadu do suchego lodu $1: 1$ stwierdzono wzrost mętności cieczy nadosadowej o $320 \mathrm{mg} \mathrm{SiO} / \mathrm{dm}^{3}$ oraz wzrost wartości ChZT $\mathrm{Cr}_{\mathrm{r}}$ o $549 \mathrm{mg} \mathrm{O} / \mathrm{dm}^{3}$ wyrażającej uwolnienie materii organicznej do fazy płynnej.
\end{abstract}

Słowa kluczowe: osad nadmierny, suchy lód, Salmonella sp., Clostridium perfringens 